$\begin{array}{ll}\text { Volume } & : 05 \\ \text { Nomor } & : 02 \\ \text { Bulan } & : \text { Mei } \\ \text { Tahun } & : 2019 \\ \text { http } & : / / \text { ejurnal.pps.ung.ac.id/index.php/AKSARA/index }\end{array}$

\title{
PENGARUH LAMA PENYIMPANAN TELUR AYAM RAS PADA SUHU REFRIGERATOR TERHADAP JUMLAH BAKTERI
}

\author{
Syam S. Kumaji \\ Universitas Negeri Gorontalo \\ syamkumaji@gmail.com
}

Received: 29 Februari 2019; Revised: 12 April 2019; Accepted: 15 April 2019

\begin{abstract}
ABSTRAK
Penelitian ini bertujuan untuk mengetahui pengaruh lama penyimpanan telur ayam ras pada suhu refrigerator terhadap jumlah bakteri. Metode yang digunakan dalam penelitian ini adalah metode rancangan acak lengkap dengan 5 (lima) perlakuan dan 5 (lima) ulangan. Perlakuan yang dimaksud adalah perlakuan tanpa penyimpanan pada suhu refrigerator, perlakuan dengan penyimpanan selama 7 hari, 14 hari, 21 hari dan 28 hari pada suhu refrigerator. Hasil penelitian juga menunjukkan bahwa terdapat perbedaan yang nyata jumlah bakteri pada telur ayam ras selama masa penyimpanan pada suhu refrigrator. Dari hasil perhitungan

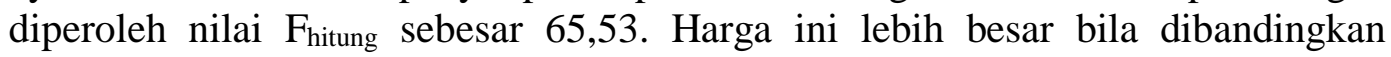
dengan $\mathrm{Ft}_{\text {abel }}$ pada taraf signifikan $\alpha=0,05$ dengan derajat bebas pembilang $\left(\mathrm{v}_{1}\right)=$ 4 dan derajat luas penyebut $\left(v_{2}\right)=20$ atau $F o=0,05(4,20)=2,87$. Dengan demikian hipotesis tentang terdapat pengaruh lama penyimpanan telur ayam ras pada suhu refrigerator terhadap jumlah bakteri diterima.
\end{abstract}

\section{PENDAHULUAN}

Seiring dengan bertambahnya jumlah penduduk maka sangatlah penting untuk menyediakan sumber pangan yang bermutu baik. Setiap pangan akan dianggap baik apabila memenuhi persyaratan gizi terutama ditinjau dari segi kualitas dan kuantitas bahan pangan itu sendiri. Bahan pangan yang baik adalah bahan pangan yang mengandung zat gizi diantaranya adalah protein baik protein nabati maupun protein hewani. Telur sebagai salah satu sumber protein hewani memiliki andil yang sangat besar dalam usaha mengatasi masalah gizi dalam masyarakat.

Telur pada umumnya digemari masyarakat karena harganya terjangkau dan sarat akan zat gizi yang diperlukan oleh tubuh. Sehubungan dengan kandungan zat gizi pada telur Astawan (2005) mengemukakan bahwa:

Zat-zat gizi yang ada pada telur sangat mudah dicerna, rasanya enak, menimbulkan rasa segar dan kuat pada tubuh serta dapat diolah menjadi berbagai macam produk makanan. Itulah sebabnya telur sangat dianjurkan untuk dikonsumsi oleh anak-anak yang masih dalam masa tumbuh kembang, ibu hamil dan menyusui, orang yang sedang sakit atau dalam masa penyembuhan, serta para lansia. Dengan kata lain, telur cocok untuk semua kelompok umur dari segala lapisan masyarakat.

Sebagai bahan pangan, telur merupakan bahan yang mudah mengalami kerusakan. Kerusakan pada telur dapat terjadi secara fisik, kimia maupun biologis sehingga terjadi perubahan selama masa penyimpanan. Oleh karena itu dalam pemilihan telur perlu memperhatikan kualitasnya. Menurut Sudaryani (2000 : 12) 


$\begin{array}{ll}\text { Volume } & : 05 \\ \text { Nomor } & : 02 \\ \text { Bulan } & : \text { Mei } \\ \text { Tahun } & : 2019 \\ \text { http } & : \text { //ejurnal.pps.ung.ac.id/index.php/AKSARA/index }\end{array}$

bahwa "Secara keseluruhan kualitas sebutir telur tergantung pada kualitas telur sebelah dalam (isi telur) dan kualitas telur bagian luar (kulit telur)".

Secara biologis kerusakan pada telur disebabkan oleh mikroorganisme diantaranya adalah bakteri. Kerusakan telur oleh bakteri terjadi karena bakteri masuk ke dalam telur sejak telur berada di dalam maupun telur sudah berada di luar tubuh induknya. Kerusakan telur oleh bakteri sejak berada di dalam tubuh induknya terjadi misalnya induk menderita salmonellosis sehingga telur mengandung bakteri Salmonella sp. Sedangkan masuknya bakteri ke dalam telur setelah telur berada di luar tubuh induknya misalnya berasal dari kotoran yang menempel pada kulit telur. Kotoran tersebut diantaranya adalah tinja, tanah atau suatu bahan yang banyak mengandung bakteri perusak. Bakteri ini masuk ke dalam telur melalui kulit telur yang retak atau menembus kulit ketika lapisan tipis protein yang menutupi kulit telur telah rusak dan lubang-lubang kecil yang terdapat pada permukaan telur yang disebut pori-pori.

Metode pendinginan pada telur bisa dilakukan dengan cara penyimpanan pada suhu refrigerator yakni pada suhu $10^{\circ} \mathrm{C}$. Penyimpanan bahan pangan pada suhu refrigerator dapat memperlambat reaksi metabolisme, selain itu juga dapat mencegah pertumbuhan mikroorganisme penyebab kerusakan atau kebusukan bahan pangan (Anonim, 2005). Lebih lanjut Moeljanto (1982 : 6) menjelaskan bahwa suhu refrigerator sangat efektif untuk menghambat pertumbuhan bakteri terutama bakteri-bakteri yang tidak tahan pada suhu dingin.

Penyimpanan telur pada suhu refrigerator dengan tujuan untuk mempertahankan kualitas telur sebaiknya memperhatikan lama dan suhu penyimpanan karena hal ini bisa mengakibatkan perubahan kualitas telur itu sendiri. Namun, fenomena yang yang terjadi pada masyarakat mereka cenderung kurang memperhatikan ataupun mengabaikan faktor suhu dan lama penyimpanan sehingga akibatnya sering diperoleh telur yang sudah rusak ataupun busuk pada saat dikonsumsi.

Berdasarkan uraian di atas maka penulis mencoba melakukan penelitian mengenai pengaruh lama penyimpanan telur ayam ras pada suhu refrigerator terhadap jumlah bakteri.

\section{TINJAUAN PUSTAKA}

\section{Struktur Umum Telur}

Telur merupakan alat perkembangbiakan bagi unggas dan sebagian hewan. Telur secara alami disiapkan oleh induknya untuk menunjang kehidupan dan perkembangan embrio dengan sempurna. Selain dibungkus dengan kulit yang keras sebagai pelindung, telur juga dilengkapi dengan bahan makanan yang lengkap. Menurut Buckle, dkk (1985 : 306) bahwa "Telur ayam mempunyai struktur yang sangat khusus yang mengandung zat gizi yang cukup untuk mengembangkan sel yang telah dibuahi menjadi seekor ayam".

Bila kita tinjau secara umum telur memiliki tiga komponen utama yakni kerabang (kulit telur, cangkang telur), putih telur (albumen) dan kuning telur (yolk). Sarwono (1994:5) mengatakan "Bahwa komposisi telur secara fisik terdiri dari $10 \%$ kerabang (kulit telur, cangkang), $60 \%$ putih telur dan $30 \%$ kuning telur". Secara terperinci struktur telur dapat dilihat pada Gambar 1 (Hadiwiyoto 1983 : 138). 


$\begin{array}{ll}\text { Volume } & : 05 \\ \text { Nomor } & : 02 \\ \text { Bulan } & : \text { Mei } \\ \text { Tahun } & : 2019 \\ \text { http } & : \text { //ejurnal.pps.ung.ac.id/index.php/AKSARA/index }\end{array}$

\section{Kulit Telur}

Kulit telur merupakan bagian telur yang paling keras dan berfungsi sebagai pelindung atau penjaga isi telur dari serangan bibit perusak dari luar. Kulit telur terdiri atas 4 (empat) bagian utama yakni kutikula, lapisan bunga karang, lapisan mamilla dan lapisan membrana.

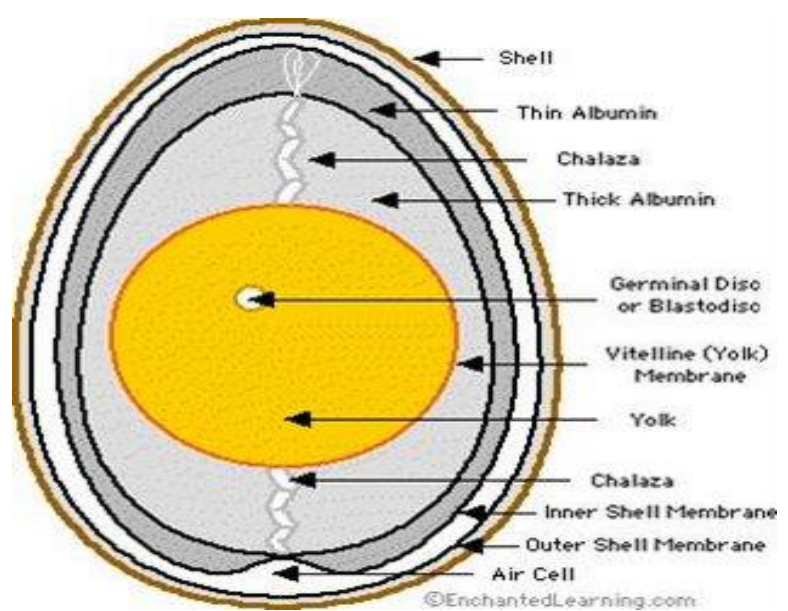

\section{Gambar 1. Struktur Telur}

Sudaryani (2000 : 14) mengatakan bahwa "Warna kulit telur ayam ras ada dua macam yaitu putih dan coklat". Perbedaan warna kulit tersebut disebabkan adanya pigmen cephorpyrin yang terdapat pada permukaan telur yang berwarna coklat.

Pada permukaan kulit telur apabila diteliti maka terdapat struktur yang berpori (poreus). Bentuk pori bermacam-macam, tergantung dari jenis telur dan letaknya pada permukaan telur. Menurut Sarwono (1994 : 9) bahwa pada telur ayam terdapat beberapa macam bentuk pori-pori misalnya bentuk bulat, bercabangcabang, panjang dan lain-lain dengan ukuran yang sangat bervariasi. Lebarnya berkisar antara $9-38$ mikron, sedangkan panjangnya antara $14-54$ mikron. Lebih lanjut Freemen (1984 : 420) mengatakan bahwa jumlah pori-pori pada telur adalah sebanyak 7.000 - 17.000 buah dengan diameter permukaan luar adalah 15$65 \mu \mathrm{m}$ sedangkan permukaan dalam adalah 6-23 $\mu \mathrm{m}$.

Banyaknya pori-pori ini bisa memberikan peluang yang besar untuk masuknya bakteri ke dalam telur. Hal ini disebabkan bakteri yang masuk ke dalam telur memiliki ukuran yang sangat kecil apabila dibandingkan dengan besarnya ukuran pori-pori pada telur. Menurut Taringan (1988 : 141) bahwa "Sel bakteri sangat kecil, kebanyakan diameternya kira-kira $0,1-0,5 \mu \mathrm{m}$ ". Dengan masuknya bakteri ke dalam telur akan menyebabkan kerusakan pada telur misalnya terjadi pembusukan pada telur akibat aktivitas bakteri.

\section{Kuning Telur}

Kuning telur memiliki bentuk yang hampir bulat, berwarna kuning sampai jingga dan biasanya terbungkus oleh selaput tipis (membrana vitelina) yang 


$\begin{array}{ll}\text { Volume } & : 05 \\ \text { Nomor } & : 02 \\ \text { Bulan } & : \text { Mei } \\ \text { Tahun } & : 2019 \\ \text { http } & : \text { //ejurnal.pps.ung.ac.id/index.php/AKSARA/index }\end{array}$

sangat kuat dan elastis. Kuning telur memiliki komposisi gizi yang sangat lengkap yakni terdiri dari air, protein, lemak, karbohidrat, mineral dan vitamin.

Pada kuning telur terdapat inti telur yang berupa bintik putih. "Benih atau blastodisc yang terlihat sebagai bintik kecil pada permukaan kuning telur apabila dibuahi maka akan berkembang menjadi anak ayam" (Buckle, dkk. 1985 : 306).

\section{Putih Telur}

Putih telur terdapat di antara kulit telur dan kuning telur. Banyaknya putih telur sekitar $60 \%$ dari seluruh telur. Menurut Winarno (2002 : 7) bahwa putih telur mengandung 12 jenis protein yakni ovalbumin, ovomukoid, ovomusin, conalbumin, ovoglikoprotein, ovomacroglobulin, ovoinhibitor, ovoglobulin G1, ovoglobulin G2, lisozim, flavoprotein dan avidin. Karbohidrat juga terdapat pada putih telur, tetapi jumlahnya sedikit sekali.

Sarwono (1994 : 10) menyatakan bahwa "Putih telur terdiri atas 4 (empat) lapisan, yaitu lapisan luar 23,2 \%, lapisan tengah 53,7 \%, lapisan dalam 16,9\% dan lapisan kalazifera 2,7 \%”. Di bagian putih telur juga terdapat protein antimikroba yang disebut lisozim. Fungsi protein tersebut adalah membantu memperlambat proses kerusakan telur.

\section{Nilai Gizi Telur}

Telur adalah salah satu sumber protein hewani yang memiliki rasa yang sangat lezat, mudah dicerna dan bergizi tinggi. Haryoto (1996 : 9) menyatakan bahwa "Telur memiliki kandungan gizi yang hampir sempurna, sebab merupakan persediaan pangan selama embrio mengalami perkembangan di dalam telur, tanpa makanan tambahan dari luar".

Menurut Haryoto (1996 : 10) bahwa kandungan gizi sebutir telur ayam dengan berat $100 \mathrm{~g}$ terdiri dari protein $12,8 \mathrm{~g}$, karbohidrat $0,7 \mathrm{~g}$, lemak 11,5 g, vitamin dan mineral. Kandungan gizi yang terdapat pada telur ayam selengkapnya disajikan pada Tabel 1.

Tabel 1. Daftar Analisis Kandungan Telur

\begin{tabular}{|l|l|l|}
\hline No & Zat Gizi & Telur Ayam \\
\hline 1 & Kalori (kal) & 162 \\
\hline 2 & Protein (gr) & 12,8 \\
\hline 3 & Lemak (gr) & 11,5 \\
\hline 4 & Karbohidrat (gr) & 0,7 \\
\hline 5 & Kalsium (gr) & 54 \\
\hline 6 & Fosfor (gr) & 180 \\
\hline 7 & Besi (mg) & 2,7 \\
\hline 8 & Vitamin A (mg) & 900 \\
\hline 9 & Vitamin B (mg) & 0,1 \\
\hline 10 & Air (gr) & 74 \\
\hline
\end{tabular}

(Sumber : Haryoto, $1996: 10$ )

\section{Kerusakan Telur Oleh Bakteri}

Bahan pangan jarang sekali dijumpai dalam keadaan steril, walaupun ada beberapa bahan pangan yang tidak dapat ditumbuhi oleh beberapa bakteri. Hampir semua bahan pangan tercemar oleh berbagai macam bakteri dari lingkungan 


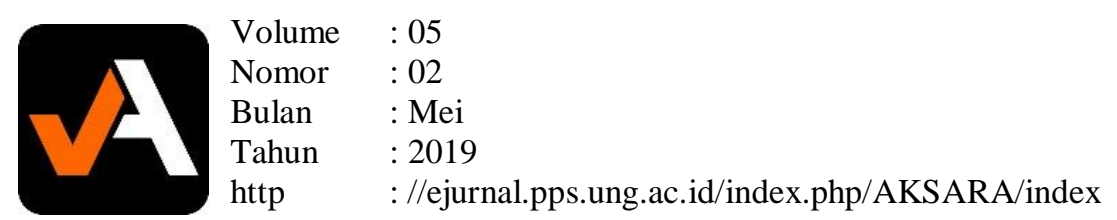

sekitarnya yaitu udara, air, tanah, debu, kotoran dan bahan organik yang telah busuk. Buckle (1985 : 69) menyatakan bahwa "Pertumbuhan mikroorganisme dapat mengakibatkan berbagai perubahan fisik dan kimiawi dari suatu bahan makanan". Apabila perubahan tersebut tidak diinginkan atau tidak dapat diterima oleh para konsumen, maka bahan pangan tersebut dikatakan mengalami kerusakan.

Pelczar dan Chan (1988) mengatakan bahwa kerusakan pada telur umumnya disebabkan oleh bakteri yang masuk melalui kulit yang retak atau menembus kulit ketika lapisan tipis protein yang menutupi kulit telur telah rusak. Jenis bakteri yang menyebabkan kerusakan pada telur antara lain Salmonella, Campylobacter jejuni, Staphylococcus aureus, Clostridum perfringens, Vibrio vulnificus, Listeria manocytogen dan Shigella (Anonim, 2005).

Telur yang telah terkontaminasi oleh bakteri biasanya akan mudah mengalami kerusakan. Menurut Winarno (2002 : 21) bahwa "Kerusakan pada telur dapat digolongkan menjadi 5 (lima) macam tipe yakni green rot (disebabkan oleh bakteri Pseudomonas fluorescens), colourless rot (disebabkan oleh bakteri Pseudomonas, Achromobacter), black rot (disebabkan oleh bakteri Proteus, Pseudomonas, Aeromonas), pink rot (disebabkan oleh bakteri Pseudomonas) dan red rot (disebabkan oleh bakteri Serratia)".

Untuk memperbaiki mutu mikrobiologis telur, maka perlu ada persyaratan standar mikrobiologis yang harus dipenuhi. Oleh karena itu perlu ditetapkan peraturan-peraturan dan rekomendasi tentang persyaratan kandungan bakteri. Persyaratan cemaran mikroba oleh DEPTAN (SNI No. 01-6366-2000) seperti tercantum pada Tabel 2.

\section{Tabel 2. Persyaratan Cemaran Mikroba Pada Telur}

\begin{tabular}{|l|l|l|l|l|}
\hline \multirow{2}{*}{ No } & \multirow{2}{*}{ Jenis Cemaran Mikroba } & \multicolumn{2}{l|}{$\begin{array}{l}\text { Batas Maksimum Cemaran Mikroba (BMCM) } \\
(\text { CFU/gram) }\end{array}$} \\
\cline { 3 - 5 } & & Telur Segar & $\begin{array}{l}\text { TelurTepung / } \\
\text { Kering }\end{array}$ & Telur Beku \\
\hline 1. & Jumlah total bakteri & $1 \times 10^{5}$ & $<2,5 \times 10^{3}$ & $<2,5 \times 10^{3}$ \\
2. & Coliform & $1 \times 10^{2}$ & $<1 \times 10^{1}$ & $<1 \times 10^{1}$ \\
3. & Escherchia coli $\left(^{*}\right)$ & $1 \times 10^{1}$ & $1 \times 10^{1}$ & $1 \times 10^{1}$ \\
4. & Enteroccoci & $1 \times 10^{2}$ & $<1 \times 10^{1}$ & $<1 \times 10^{1}$ \\
5. & Staphylococcus aureus & $1 \times 10^{2}$ & 0 & $1 \times 10^{1}$ \\
6. & Clostridium sp. & 0 & 0 & 0 \\
7. & Salmonella sp. $(* *)$ & Negatif & Negatif & Negatif \\
8. & Camphylobacter $s p$ & 0 & 0 & 0 \\
9. & Listeria sp. & 0 & 0 & 0 \\
\hline
\end{tabular}

(Sumber : Departemen Pertanian, 2004)

Keterangan :

(*) : Dalam satuan MPN/gram

$(* *) \quad$ : Dalam satuan kualitatif

CFU : Colony Forming Unit

Pengawetan Telur Dengan Penyimpanan Pada Suhu Refrigerator 


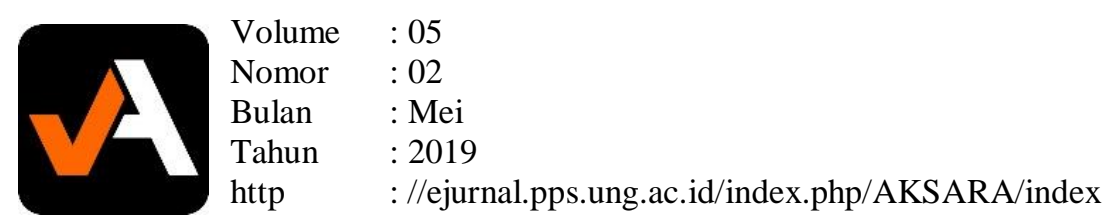

Pengawetan bahan pangan telah lama dikenal dan dijalankan oleh penghunipenghuni daerah dingin maupun daerah panas. Sebagai bahan pangan telur merupakan bahan yang mudah mengalami kerusakan. Kerusakan pada telur dapat terjadi secara fisik, biologi maupun kimia.

Untuk mencegah terjadinya kerusakan pada telur, maka dibutuhkan penanganan yang sangat tepat agar nilai gizinya tetap tinggi, tidak berubah rasa, tidak berbau busuk dan warna isinya tidak pudar. Oleh karena itu diperlukan metode-metode pengawetan telur yang bertujuan untuk mempertahankan kandungan air dan karbondioksida yang telah ada dalam telur selama mungkin dan memperlambat kegiatan mikroorganisme. Pelczar dan Chan (1988) mengatakan bahwa "Pemilihan metode pengawetan harus disertai dengan pemahaman akan adanya resistensi yang luar biasa pada spora bakteri terhadap berbagai faktor seperti panas, radiasi, bahan kimia dan dehidrasi".

Salah satu pengawetan yang dilakukan dalam menjaga mutu isi telur adalah dengan cara penyimpanan pada suhu refrigerator. Penyimpanan telur pada suhu refrigerator dapat memperlambat reaksi metabolisme. Selain itu dapat mencegah pertumbuhan mikroorganisme penyebab kerusakan atau kebusukan bahan pangan. Lebih lanjut Moeljanto (1982 : 6) mengatakan bahwa suhu refrigerator sangat efektif untuk menghambat pertumbuhan bakteri terutama bakteri-bakteri yang tidak tahan pada suhu dingin.

Dalam proses penyimpanan ini, telur utuh sebaiknya disimpan sedekat mungkin di atas titik beku telur, misalnya pada suhu sekitar $10^{\circ} \mathrm{C}$. Menurut Winarno (2002 : 24) bahwa dalam proses penyimpanan telur pada suhu refirgerator sebaiknya telur disimpan sedekat mungkin di atas titik beku telur yaitu pada suhu $2^{\circ} \mathrm{C}$.

\section{METODOLOGI PENELITIAN}

Penelitian ini dilaksanakan di laboratorium Mikrobiologi Jurusan Pendidikan Biologi Fakultas MIPA Universitas Negeri Gorontalo.

Dalam penelitian ini yang menjadi subjek penelitian adalah 25 butir telur ayam ras yang diambil dari peternakan ayam ras "Simpatik" di Kelurahan Tuladenggi, Kecamatan Dungingi, Kota Gorontalo yang diambil pada ayam dengan umur $1 \frac{1 / 2}{2}$ tahun dengan waktu pengambilan pada rentangan waktu antara pukul $12.00-16.00$ wita.

Untuk memperoleh data yang diperlukan dalam penelitian ini maka peneliti mengadakan pengamatan langsung pada obyek yang diteliti.

Untuk menganalisis data digunakan uji analisis varians (ANAVA) dengan rancangan acak lengkap (RAL).

\section{HASIL PENELITIAN DAN PEMBAHASAN}

Sebagaimana yang telah diuraikan di atas bahwa dalam penelitian ini variabel yang akan diamati adalah jumlah bakteri pada telur ayam ras. Untuk itu data yang dianalisis merupakan rata-rata akumulasi jumlah ulangan dari setiap perlakuan untuk masing-masing perlakuan. Adapun perlakuan yang dimaksud adalah sebagai berikut.

1. Perlakuan A: telur ayam ras yang tidak disimpan pada suhu refrigerator (telur segar). 


$\begin{array}{ll}\text { Volume } & : 05 \\ \text { Nomor } & : 02 \\ \text { Bulan } & : \text { Mei } \\ \text { Tahun } & : 2019 \\ \text { http } & : \text { //ejurnal.pps.ung.ac.id/index.php/AKSARA/index }\end{array}$

2. Perlakuan B: telur ayam ras yang disimpan pada suhu refrigerator selama 7 hari.

3. Perlakuan $\mathrm{C}$ : telur ayam ras yang disimpan pada suhu refrigerator selama 14 hari.

4. Perlakuan D : telur ayam ras yang disimpan pada suhu refrigerator selama 21 hari.

5. Perlakuan E : telur ayam ras yang disimpan pada suhu refrigerator selama 28 hari.

Hasil penghitungan jumlah bakteri pada telur ayam ras yang disimpan pada suhu refrigerator selama 7 hari, 14 hari, 21 hari dan 28 hari dapat dilihat pada Tabel 5.

Tabel 5. Hasil Pengamatan Jumlah Bakteri Pada Telur Ayam Ras Selama Masa Penyimpanan Pada Suhu Refrigerator ( x $10^{3}$ CFU/l gram )

\begin{tabular}{|l|l|l|l|l|l|}
\hline \multirow{2}{*}{ Ulangan } & \multicolumn{5}{l}{ Perlakuan } \\
\cline { 2 - 6 } & $\mathrm{A}$ & $\mathrm{B}$ & $\mathrm{C}$ & $\mathrm{D}$ & $\mathrm{E}$ \\
\hline 1 & 0 & 14,8 & 14,6 & 9,6 & 7,6 \\
\hline 2 & 0 & 17,8 & 11,2 & 10,2 & 5,4 \\
\hline 3 & 0 & 14,6 & 14,2 & 5,8 & 4,2 \\
\hline 4 & 0 & 18,2 & 13,4 & 5,2 & 8,4 \\
\hline 5 & 0 & 19,4 & 10,6 & 8,2 & 5,0 \\
\hline Jumlah & 0 & 84,8 & 64 & 39 & 30,6 \\
\hline Rata-rata & 0 & 16,96 & 12,8 & 7,8 & 6,12 \\
\hline
\end{tabular}

Berdasarkan Tabel 5 dapat diketahui bahwa jumlah bakteri pada telur ayam ras akan berkurang dengan bertambah lamanya penyimpanan pada suhu refrigerator. Rata-rata jumlah bakteri pada telur ayam ras tanpa penyimpanan adalah $0 \times 10^{3} \mathrm{CFU} / \mathrm{gr}$, pada penyimpanan 7 hari adalah $16,96 \times 10^{3} \mathrm{CFU} / \mathrm{gr}$, pada penyimpanan 14 hari adalah $12,8 \times 10^{3} C F U / g r$, pada penyimpanan 21 hari adalah $7,7 \times 10^{3} C F U / g r$ dan pada penyimpanan selama 28 hari adalah $6,12 \times 10^{3}$ CFU/gr. Untuk memperjelas perbedaan jumlah rata-rata bakteri untuk setiap perlakuan disajikan grafik diagram batang pada Gambar 2.

Analisis Statistik Data Hasil Penelitian

Pada bab sebelumnya telah dikemukakan bahwa analisis yang digunakan dalam pengujian hipotesis adalah analisis varians (ANAVA) sedangkan untuk melihat perbedaan dari tiap-tiap perlakuan menggunakan uji beda nyata terkecil (BNT).

Hipotesis yang digunakan dapat dirumuskan dalam bentuk matematis sebagai berikut.

Ho $=0$

$\mathrm{Ha} \neq 0$

Di mana :

Ho : lama penyimpanan telur ayam ras pada suhu refrigerator tidak memberikan pengaruh terhadap jumlah bakteri. 


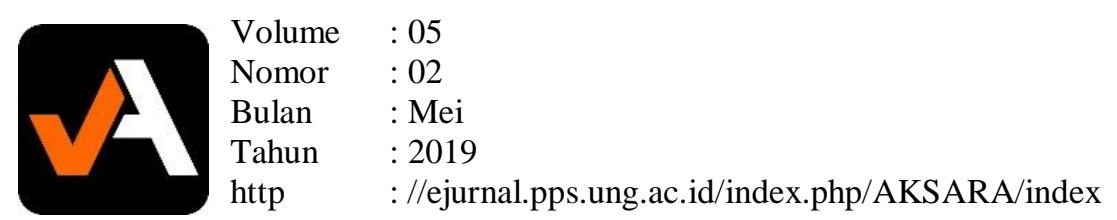

Ha : lama penyimpanan telur ayam ras pada suhu refrigerator memberikan pengaruh terhadap jumlah bakteri.

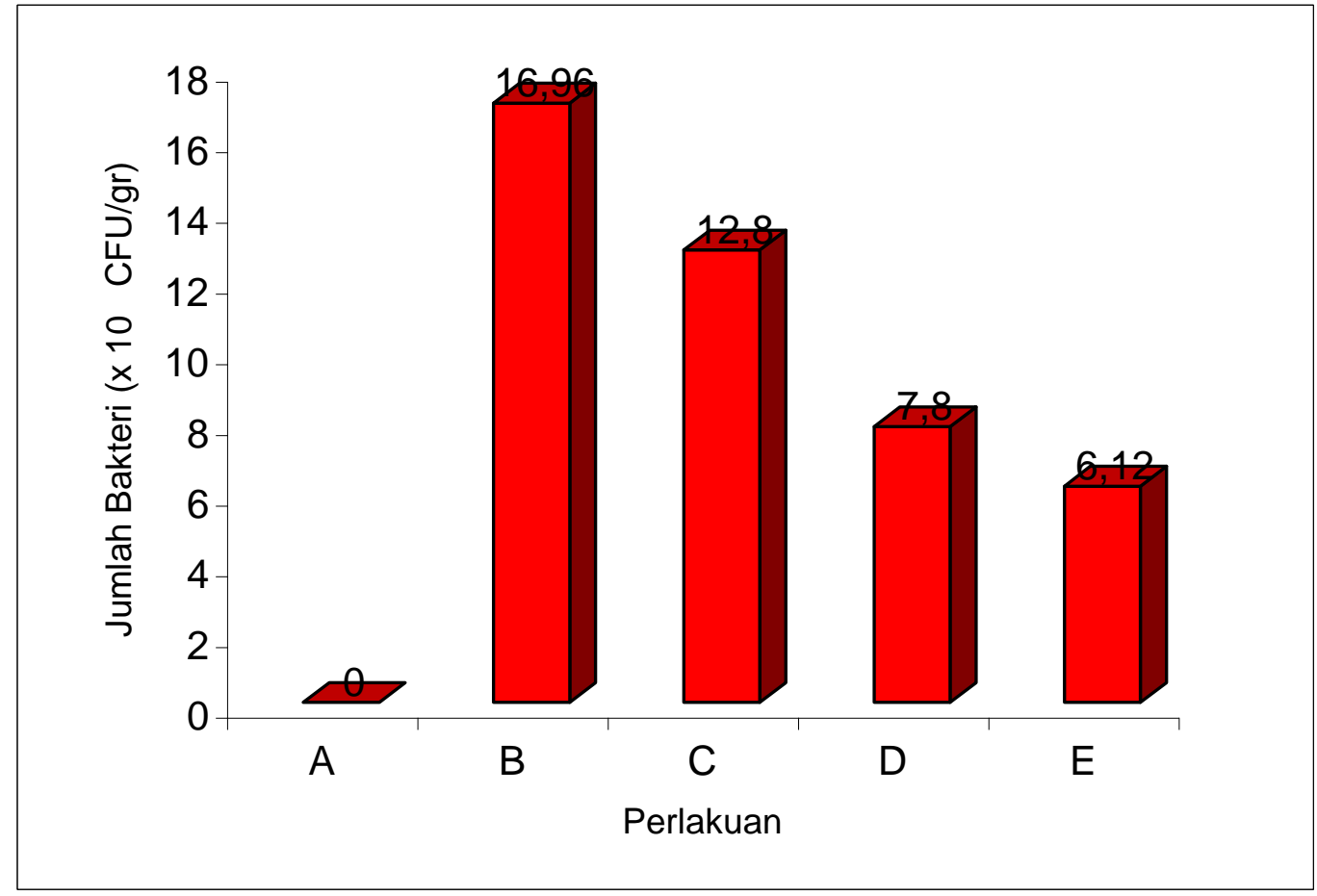

Gambar 2. Digram Batang Rata-Rata Jumlah Bakteri Pada Telur Ayam Ras Selama Masa Penyimpanan Pada Suhu Refrigerator.

Dengan menggunakan data pada Tabel 5 maka dihitung komponen ANAVA. Nilai-nilai yang diperoleh selanjutnya disusun dalam tabel analisis varians (ANAVA) pada Tabel 6.

Tabel 6. Analisis Varians Jumlah Bakteri Pada Telur Ayam Ras Selama Masa Penyimpan Pada Suhu Refrigerator

\begin{tabular}{|l|l|l|l|l|}
\hline Sumber Varians & dk & JK & KT & F \\
\hline Rata-rata & 1 & 1907,9424 & 1907,9424 & \\
\hline Antar Perlakuan & 4 & 840,9376 & 210,2344 & 65,53 \\
\hline $\begin{array}{l}\text { Kekeliruan } \\
\text { Eksperimen } \\
\text { (dalam } \\
\text { perlakuan) }\end{array}$ & 20 & 64,16 & 3,208 & \\
\hline Total & 25 & 2813,04 & - & - \\
\hline
\end{tabular}




$\begin{array}{ll}\text { Volume } & : 05 \\ \text { Nomor } & : 02 \\ \text { Bulan } & : \text { Mei } \\ \text { Tahun } & : 2019 \\ \text { http } & : \text { //ejurnal.pps.ung.ac.id/index.php/AKSARA/index }\end{array}$

Dari tabel di atas maka diperoleh nilai $\mathrm{F}_{\text {hitung }}=65,53$. Harga ini lebih besar bila dibandingkan dengan $\mathrm{F}_{\text {tabel }}$ pada taraf signifikan $\alpha=0,05$ dengan derajat bebas pembilang $\left(v_{1}\right)=4$ dan derajat luas penyebut $\left(v_{2}\right)=20$ atau $F o=0,05(4,20)$ $=2,87$. Dengan demikian terbukti bahwa $F_{\text {hitung }}>F_{\text {tabel. }}$ Hal ini menunjukkan bahwa terdapat pengaruh lama penyimpanan telur ayam ras pada suhu refrigerator terhadap jumlah bakteri.

Selanjutnya untuk melihat efek dari setiap perlakuan maka digunakan uji beda nyata terkecil (BNT). Nilai BNT yang diperoleh kemudian dibandingkan dengan selisih rata-rata tiap perlakuan. Untuk lebih jelasnya dapat dilihat pada Tabel 7.

Tabel 7. Analisis Uji Beda Nyata Terkecil (BNT) Jumlah Bakteri Pada Telur Ayam Ras Selama Masa Penyimpanan Pada Suhu Refrigerator

\begin{tabular}{|l|l|l|}
\hline Perlakuan & Rata-Rata & Notasi dengan BNT 5 \% \\
\hline A & 0 & a \\
\hline E & 6,12 & b \\
\hline D & 7,8 & b \\
\hline C & 12,8 & c \\
\hline B & 16,96 & d \\
\hline
\end{tabular}

Keterangan : Simbol (huruf) yang tidak sama menunjukkan perbedaan yang bermakna.

Berdasarkan Tabel 7, maka dapat dilihat bahwa terdapat perbedaan yang bermakna jumlah bakteri antara telur yang disimpan selama 7 hari dengan telur yang disimpan selama 14 hari, antara telur yang disimpan selama 14 hari dengan telur yang disimpan selama 21 hari. Sedangkan untuk perlakuan penyimpanan telur selama 21 hari dan 28 hari pada suhu refrigerator tidak terdapat perbedaan yang bermakna.

\section{PENUTUP}

Berdasarkan analisis statistik, bahwa lama penyimpanan telur ayam ras pada suhu refrigerator berpengaruh terhadap jumlah bakteri. Dengan demikian hipotesis tentang terdapat pengaruh lama penyimpanan telur ayam ras pada suhu refrigerator terhadap jumlah bakteri diterima. Hal ini dibuktikan dari hasil analisis varians (ANAVA), di mana diperoleh harga $F_{\text {hitung }}=65,53$ nilai ini lebih besar bila dibandingkan dengan $F_{\text {tabel }}$ pada taraf signifikansi $\alpha=0,05$ dengan derajat ebas pembilang $\quad\left(v_{1}\right)=4$ dan derajat luas penyebut $\left(v_{2}\right)=20$ atau $\mathrm{Fo}=0,05$ $(4,20)=2,87$.

Dari uji beda nyata terkecil (BNT) terhadap variabel yang diamati ternyata di antara perlakuan D ( penyimpanan 21 hari) dan perlakuan E (penyimpanan 28 hari) tidak terdapat perbedaan yang bermakna, sebaliknya pada perlakuan A (tanpa penyimpanan) dengan perlakuan $\mathrm{B}$ (penyimpanan 7 hari) serta antara perlakuan B (penyimpanan 7 hari) dengan perlakuan C (penyimpanan 14 hari) terdapat perbedaan yang bermakna. 


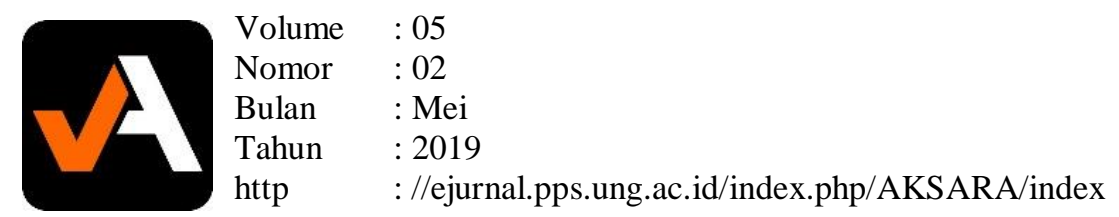

\section{DAFTAR PUSTAKA}

Anonim. 2005. Cara Menghindari Kontaminasi atau Keracunan Makanan.

Tersedia : http : www. google. com.

Aryastami, K. 1994. Telur dan Kandungan Gizinya. Dharma Wanita. Hal. 70-71.

Astawan, M. 2005. Telur Asin. Depkes. Tersedia : http : www. depkes. go. id.

Buckle, K. A. 1985. Ilmu Pangan. Jakarta : Universitas Indonesia.

Deptan. 2004. Veteriner Residu. Tersedia : http : www.google.com.

Fardiaz, S. 1993. Analisis Mikrobiologi Pangan. Jakarta : Djambatan.

1992. Mikrobiologi Pangan 1. Jakarta : Gramedia Pustaka Utama.

Freeman, B.M. 1984. Phsiology and Biochemistry of The Domestic Fowl.

London : Academic Press Inc.

Hadiwiyoto, S. 1983. Hasil-Hasil Olahan Susu, Ikan, Daging dan Telur. Yogyakarta : Liberty.

Hanafiah, A.K. 2003. Rancangan Percobaan. Jakarta : Raja Grafindo Perkasa.

Haryoto. 1996. Pengawetan Telur Segar. Yogyakarta : Kanisius.

Hermawati, D. 2000. Penetapan Kebijakan Pemerintah Terhadap Keamanan Produk Peternakan Menghadapi Era Perdagangan Bebas Melalui Metode Ilmiah dan Pendekatan Ilmu Interdisiplin. Makalah. Program Pascasarjana : IPB Bogor.

Ishak, E. 1985. Ilmu dan Teknologi Pangan. Ujung Pandang : BKS PTN INTIM.

Menristek. 2005. Tekhnologi Tepat Guna Tentang Pengolahan Pangan, Pengawetan dan Bahan Kimia II. Tersedia : http : www. yahoo. com.

Moeljanto. 1982. Pendinginan dan Pembekuan Ikan. Jakarta : Penebar Swadaya.

Pelczar dan Chan. 1988. Dasar-Dasar Mikrobiologi Jilid 2. Jakarta : Universitas Indonesia.

Sarwono, B. 1994. Pengawetan dan Pemanfaatan Telur. Jakarta : Penebar Swadaya.

Sudaryani, T. 2000. Kualitas Telur. Jakarta : Penebar Swadaya.

Sudjana. 1989. Metode Statistik. Bandung : Tarsito.

1995. Desain dan Analisis Eksperimen. Bandung : Tarsito.

Taringan, J. 1988. Pengantar Mikrobiologi. Jakarta : Depdikbud.

Winarno, F.G. 2002. Telur : Komposisi, Penanganan dan Pengolahannya. Bogor : M-Brio Press. 